OPEN ACCESS

Edited by:

Julia Ribeiro,

Rice University, United States

Reviewed by:

Christopher Robert Pearce

National Oceanography Centre,

United Kingdom

Weiqiang Li,

Nanjing University, China

*Correspondence:

Philip A. E. Pogge von Strandmann p.strandmann@ucl.ac.uk

Specialty section:

This article was submitted to

Geochemistry,

a section of the journal

Frontiers in Earth Science

Received: 05 October 2018

Accepted: 17 January 2019

Published: 01 February 2019

Citation:

Pogge von Strandmann PAE,

Olsson J, LuU T-H, Gislason SR and

Burton KW (2019) Using Mg Isotopes

to Estimate Natural Calcite

Compositions and Precipitation Rates

During the 2010 Eyjafjallajökull

Eruption. Front. Earth Sci. 7:6.

doi: 10.3389/feart.2019.00006

\section{Using Mg Isotopes to Estimate Natural Calcite Compositions and Precipitation Rates During the 2010 Eyjafjallajökull Eruption}

\author{
Philip A. E. Pogge von Strandmann ${ }^{1 *}$, Jonas Olsson², Tu-Han Luu, \\ Sigurður R. Gislason ${ }^{4}$ and Kevin W. Burton ${ }^{5}$
}

' LOGIC, Institute of Earth and Planetary Sciences, University College London, Birkbeck, University of London, London, United Kingdom, ${ }^{2}$ Chemical Division, Danish Emergency Management Agency, Copenhagen, Denmark, ${ }^{3}$ BIG, School of Earth Sciences, University of Bristol, Bristol, United Kingdom, ${ }^{4}$ Institute of Earth Sciences, University of Iceland, Reykjavik, Iceland, ${ }^{5}$ Department of Earth Sciences, Durham University, Durham, United Kingdom

Chemical weathering of silicate rocks is a key control on the long-term climate, via drawdown of atmospheric $\mathrm{CO}_{2}$. Magnesium isotopes are increasingly being used to trace weathering, but are often complicated by several coincident fractionating processes. Here we examine $\mathrm{Mg}$ isotope ratios of waters stemming from beneath lava flows from the 2010 Eyjafjallajökull eruption. Travertine calcite was observed directly precipitating from these high-TDS (total dissolved solids) waters, and were also sampled. This system therefore provides the opportunity to study natural Mg isotope fractionation by calcite. Riverine $\delta^{26} \mathrm{Mg}$ increase from -2.37 to $+0.43 \%$ with flow distance, as isotopically light travertine precipitates $\left(\delta^{26} \mathrm{Mg}=-3.38\right.$ to $\left.-3.94 \%\right)$. The solution $\mathrm{Mg}$ isotope ratios also co-vary with $\mathrm{pH}$, calcite saturation indices and $\mathrm{Sr} / \mathrm{Ca}$ ratios, strongly indicating that they are dominantly controlled by carbonate precipitation. Using experimental isotopic fractionation factors and the measured $\delta^{26} \mathrm{Mg}$ values, we can predict the compositions of the precipitated travertines that are within uncertainty of the directly measured travertines. Hence, in some systems, $\mathrm{Mg}$ isotopes can be used to quantify carbonate precipitation.

Keywords: weathering, carbonate, travertine, magnesium isotopes, basalt

\section{INTRODUCTION}

The chemical weathering of silicate rocks drives a key, and likely dominant, $\mathrm{CO}_{2}$ removal process in the long-term carbon cycle (Walker et al., 1981; Berner et al., 1983; Berner, 2003). The chemical weathering of basaltic rocks, in particular, is thought to have a significantly greater influence on global atmospheric $\mathrm{CO}_{2}$ concentrations than would be expected from their global extent, with estimates suggesting they are about an order of magnitude more efficient at $\mathrm{CO}_{2}$ drawdown than a comparable area of felsic continental crust (Meybeck, 1987; Gaillardet et al., 1999; Dessert et al., 2003; Wolff-Boenisch et al., 2006). As such, studying basaltic weathering reactions provides the opportunity to understand globally significant processes. 
Therefore, tracers that inform on weathering fluxes, rates or processes have been sought. Recently, attention has focussed on magnesium isotopes (Tipper et al., 2006b; Pogge von Strandmann et al., 2008; Foster et al., 2010; Higgins and Schrag, 2010; Teng et al., 2010; Tipper et al., 2012a; Opfergelt et al., 2014; Pogge von Strandmann et al., 2014), because $\mathrm{Mg}$ is one of the elements directly involved in $\mathrm{CO}_{2}$ sequestration, via weathering of $\mathrm{Mg}$-silicates which consumes protons and creates alkalinity and the precipitation of dolomite or high$\mathrm{Mg}$ calcite in the oceans. In principle, $\mathrm{Mg}$ isotope behavior in the oceans is relatively simple, with continental weathering serving as the dominant $\mathrm{Mg}$ source, and hydrothermal removal, dolomite formation, and low-temperature clay formation all acting as sinks (Holland, 2005; Tipper et al., 2006b; Pogge von Strandmann et al., 2014). However, the study of global rivers has revealed a large range in dissolved $\mathrm{Mg}$ isotope ratios (Tipper et al., 2006a; Brenot et al., 2008; Pogge von Strandmann et al., 2008; Tipper et al., 2008, 2010; Wimpenny et al., 2011; Huang et al., 2012; Pogge von Strandmann et al., 2012; Tipper et al., 2012a,b; Liu et al., 2014), and it has become clear that, like all major elements, $\mathrm{Mg}$ and its isotopes are affected by a wide range of processes. The balance of carbonate to silicate in a catchment plays a significant role, with carbonates being isotopically lighter than silicates (Tipper et al., 2008; Pogge von Strandmann et al., 2014). The amount of $\mathrm{Mg}$ isotope fractionation during carbonate precipitation also appears to be dependent upon mineralogy (Immenhauser et al., 2010; Wombacher et al., 2011; Geske et al., 2012; Saulnier et al., 2012; Geske et al., 2015), organic vs. inorganic precipitation (Chang et al., 2004; Pogge von Strandmann, 2008; Saenger and Wang, 2014), precipitation rate (Mavromatis et al., 2013), fractionation mechanism (Buhl et al., 2007), and potentially speciation (Schott et al., 2016), resulting in a wide range in isotope ratios. In addition, $\mathrm{Mg}$ isotopic fractionation occurs due to the silicate weathering process itself, owing to both preferential incorporation and adsorption of $\mathrm{Mg}$ isotopes by secondary minerals (Pogge von Strandmann et al., 2008; Opfergelt et al., 2010, 2011; Huang et al., 2012; Pogge von Strandmann et al., 2012; Tipper et al., 2012a; Liu et al., 2014). Finally, the uptake of $\mathrm{Mg}$ by plants causes variable isotope fractionation (Black et al., 2006; Bolou-Bi et al., 2010, 2012).

To a great extent, the difficulty of interpreting the $\mathrm{Mg}$ system is enhanced because none of the above processes occur in isolation. In this study, however, there is that possibility. In 2010, the eruption of the Eyjafjallajökull volcano created a spring outlet from under the new lava flow. The water in this stream was shown to have extremely high total dissolved solids (Olsson et al., 2014), and travertine (calcite) was observed precipitating from these waters at several points downstream. It is therefore possible to examine $\mathrm{Mg}$ isotope fractionation occurring during precipitation of a single inorganic carbonate phase (travertine calcite). This precipitation occurs at rates far faster than other secondary mineral (e.g., clay) formation, consequently it is likely that calcite is the only Mg-bearing secondary phase forming. Here, we measure the $\mathrm{Mg}$ isotope composition of these waters and travertines, to determine isotope behavior during rapid natural calcite precipitation.

\section{SAMPLES AND SETTINGS}

The 2010 Eyjafjallajökull flank eruption occurred after 18 years of seismic activity, and began from the Fimmvörouháls ridge on the 20th March (Figure 1), and lasted until the 12th of April. Following this, an explosive summit eruption started on the 14th of April and finally ended in May 2012. It was this explosive eruption that gained international fame by shutting down European airspace from the 15th to 20th April 2010 .

The samples were taken from a spring emerging from under the alkali basalt lava of the 2010 Eyjafjallajökull flank eruption within 3 months of the eruption (October 2010). The water from the spring was then further sampled downstream (Olsson et al., 2014). While no travertine was observed at the point of emergence from under the lava, significant travertine precipitated downstream, which was also sampled.

\section{MATERIALS AND METHODS}

The Eyjafjallajökull samples were collected as detailed in Olsson et al. (2014). Briefly, field measurements of temperature, conductivity and $\mathrm{pH}$ were made. Alkalinity titrations were determined within $24 \mathrm{~h}$ of sampling. Samples were filtered through $0.2 \mu \mathrm{m}$ cellulose acetate filters, and stored in pre-cleaned vials. Elemental concentrations were determined by ICP-OES and ion chromatography.

\section{Mg Isotope Ratios}

Samples were purified using dilute $\mathrm{HNO}_{3}$ as an eluent, using the AG50W X-12 resin, and analyzed on a Thermo Finnegan Neptune MC-ICP-MS at the Bristol Isotope Group (BIG) (Pogge von Strandmann et al., 2011, 2012), using a sample-standard bracketing method relative to the DSM3 standard (Galy et al., 2003). Each sample was measured four separate times during an analytical procedure, repeat measurements being separated by several hours, but during the same analysis session. Each individual measurement consisted of 20 ratios (84 s total integration time), giving a total integration time of $336 \mathrm{~s}$ /sample for the total single analysis. Reported uncertainties (Table 1) are the 2sd of these four repeats. Inter-laboratory comparisons using this method of seawater $[-0.82 \pm 0.06 \%$. 2sd, $n=26$ (Foster et al., 2010)], silicate rock standards (Pogge von Strandmann et al., 2011; Teng et al., 2015), and low temperature carbonates, soils and river waters (Shalev et al., 2018) have been published. The long-term external analytical reproducibility for $\delta^{26} \mathrm{Mg}$, based on these standards, is $\pm 0.07 \%$. Standards analyzed during the analytical sessions for this study's samples were seawater $\left(\delta^{26} \mathrm{Mg}=-0.83 \pm 0.04 \%, 2 \mathrm{sd}, n=2\right)$ and BCS-CRM 513a limestone $\left(\delta^{26} \mathrm{Mg}=-4.47 \pm 0.03 \%, 2 \mathrm{sd}, n=1\right)$, which are in agreement with published values (Foster et al., 2010; Shalev et al., 2018). 


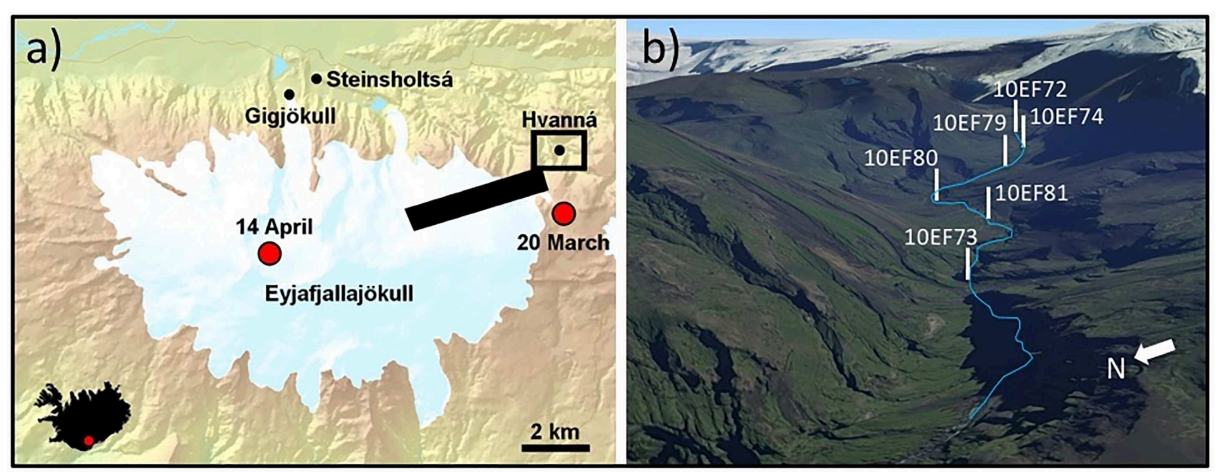

FIGURE 1 | (a) Map of Eyjafjallajökull. The red dots mark the eruption sites, the solid bar represents an expected dyke intrusion and the back box shows the sample area (modified from Olsson et al., 2014). (b) Detailed 3D map of sample area (background image from Google Maps).

\section{RESULTS}

\section{Travertines}

XRD analyses by Olsson et al. (2014) showed that calcite was the only crystalline phase in these travertine samples. The concentrations of several elements of the travertines analyzed in this study, including $\mathrm{Ca}, \mathrm{Mg}, \mathrm{Si}$, and $\mathrm{Al}$ increase with flow distance. This also causes the $\mathrm{Mg} / \mathrm{Ca}$ ratios to increase with flow distance from 8.7 to $11.8 \mathrm{mmol} / \mathrm{mol}$ (Olsson et al., 2014), which is a similar range to other inorganic calcites (Mucci, 1987; Busenberg and Plummer, 1989). Overall, these travertines have identical partition coefficients to experiments conducted on pure systems for most elements (Olsson et al., 2014).

The $\delta^{26} \mathrm{Mg}$ values of the analyzed travertine are low, ranging from -3.94 to $-3.38 \%$ (Table 1 ). These values are within the range of previously measured calcites (Chang et al., 2004; Pogge von Strandmann, 2008; Immenhauser et al., 2010; Wombacher et al., 2011; Mavromatis et al., 2013; Pogge von Strandmann et al., 2014). There is no clear trend with distance, or with elemental ratios such as $\mathrm{Mg} / \mathrm{Ca}$.

\section{Riverine Samples}

All sample analyses, locations and elemental data are given in Table 1, and also in Olsson et al. (2014). The $\mathrm{pH}$ of the waters exits the lava flow at 6.6 , but increases to 8.4 within $\sim 1300 \mathrm{~m}$, after which it remains approximately stable (Figure 2A). Most elemental concentrations in solution ( $\mathrm{Ca}, \mathrm{Mg}, \mathrm{Na}, \mathrm{Si}, \mathrm{K})$ also decrease with distance (Table 1). The individual relationships between the elements leads to $\mathrm{Mg} / \mathrm{Ca}$ ratios increasing with distance, from 0.69 to $1.23 \mathrm{~mol} / \mathrm{mol}$ (Figure 3A), i.e., two orders of magnitude higher than the corresponding travertines, which is expected from calcite partition coefficients (Mucci, 1987; Busenberg and Plummer, 1989; Olsson et al., 2014). Ca/Sr ratios decrease (from 857 to $810 \mathrm{mmol} / \mathrm{mol}$ ), providing a strong indication that carbonates are precipitating along the flow-line (Figure 3B).

The dissolved $\delta^{26} \mathrm{Mg}$ value at the spring outlet from the lava field is $-2.37 \%$, which is considerably lower than rivers or springs reported from other basaltic settings, although still over $1 \%$ higher than the travertines. This sample underwent repeated analysis through full chemistry, with both results within analytical uncertainty (Table 1). Springs from active lava fields have not been sampled before, but basaltic rivers have not been reported with $\delta^{26} \mathrm{Mg}<-1 \%$ (Pogge von Strandmann et al., 2008; Huang et al., 2012; Pogge von Strandmann et al., 2012; Liu et al., 2014). No travertine was observed at this location, possibly because of limited degassing at that time, right after the water was exposed to the atmosphere, which resulted in relatively low supersaturation, precluding nucleation and growth of the calcite. Downstream from this sample, the $\delta^{26} \mathrm{Mg}$ shifts to higher values with flow distance to $+0.43 \%$ (Figure 4 ). Travertine, calcite, was observed precipitating at locations below the outlet site after prolonged degassing as reflected by the in situ partial pressure of the carbon dioxide $\left(\mathrm{pCO}_{2}\right.$, Figure $2 \mathrm{C}$ ), as is also consistent with the high saturation state of the water with respect to calcite and decreasing $\mathrm{Ca} / \mathrm{Sr}$ ratios with flow distance (Figure 2B).

Calcite saturation states, calculated using the PHREEQC program (Parkhurst and Appelo, 1999) show the calcite SI rapidly increasing from 0.19 (i.e., within uncertainty of saturation) at the outlet, to $\sim 1.7$ (i.e., heavily super saturated) by $\sim 1300 \mathrm{~m}$ of flow (Figure 2B) (Olsson et al., 2014). The uncertainty on the saturation index must take the uncertainty on the analyses into account, and then propagate them through the PHREEQC calculations. Using our Hanna $\mathrm{pH}$ meter's certified accuracy ( $\pm 0.1 \mathrm{pH}$ units), analytical uncertainty on Ca concentrations, and a conservative $\pm 10 \%$ on alkalinity titrations, this propagates to $\pm 0.4-0.5$ SI units. Uncertainty on temperature measurements is too small to cause additional significant error.

\section{DISCUSSION}

\section{Elemental Ratios}

These samples provide the opportunity to examine $\mathrm{Mg}$ isotopes in complementary rivers and rocks. However, for the travertines and waters to be truly complementary, it must be determined that the sampled travertine was actually precipitating from these post-eruptive waters. This is confirmed because no travertine was observed at those locations before the eruption. Further, 

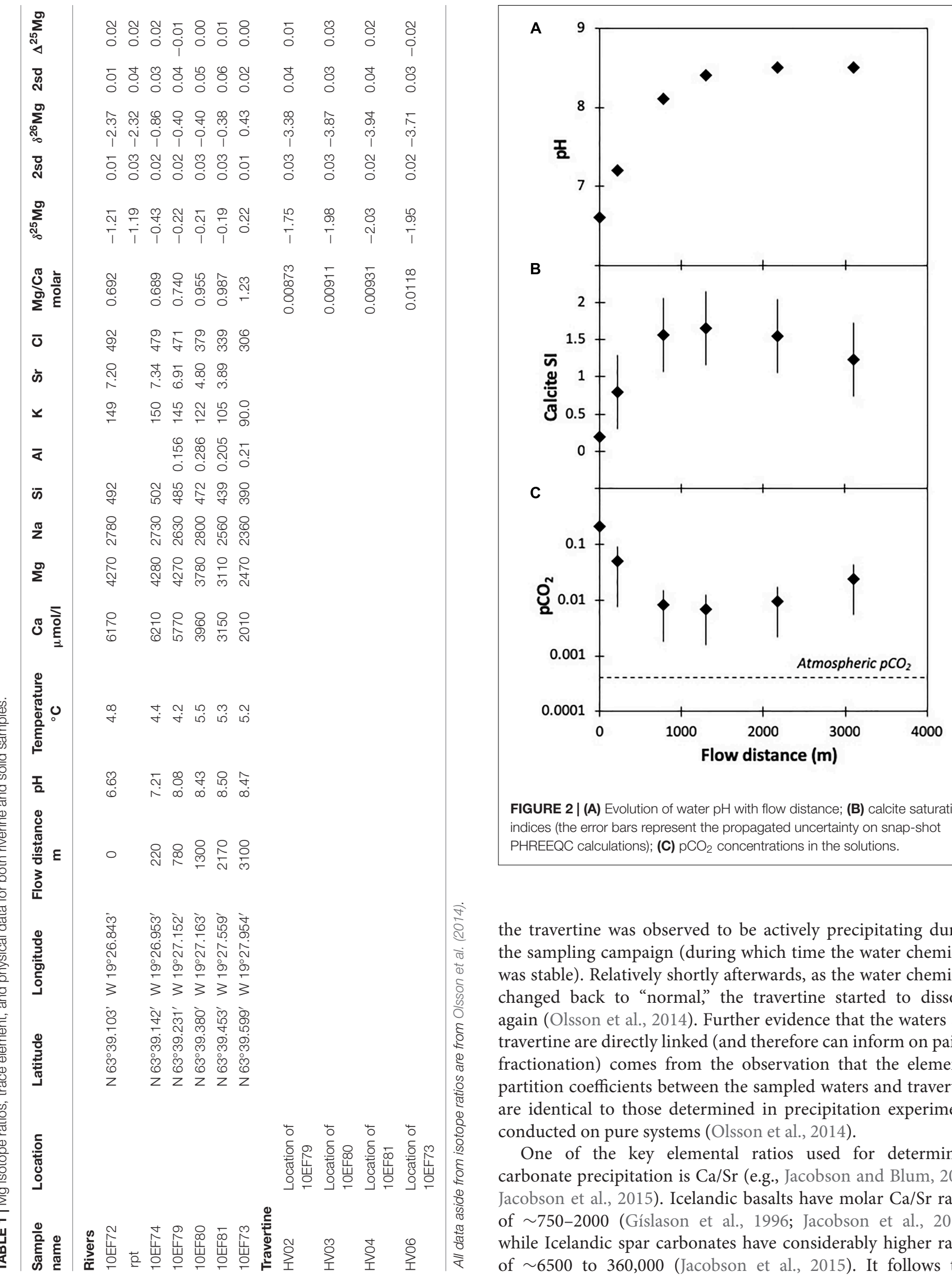

FIGURE 2 | (A) Evolution of water pH with flow distance; (B) calcite saturation indices (the error bars represent the propagated uncertainty on snap-shot PHREEQC calculations); (C) $\mathrm{pCO}_{2}$ concentrations in the solutions.

the travertine was observed to be actively precipitating during the sampling campaign (during which time the water chemistry was stable). Relatively shortly afterwards, as the water chemistry changed back to "normal," the travertine started to dissolve again (Olsson et al., 2014). Further evidence that the waters and travertine are directly linked (and therefore can inform on paired fractionation) comes from the observation that the elemental partition coefficients between the sampled waters and travertine are identical to those determined in precipitation experiments conducted on pure systems (Olsson et al., 2014).

One of the key elemental ratios used for determining carbonate precipitation is $\mathrm{Ca} / \mathrm{Sr}$ (e.g., Jacobson and Blum, 2000; Jacobson et al., 2015). Icelandic basalts have molar $\mathrm{Ca} / \mathrm{Sr}$ ratios of 750-2000 (Gíslason et al., 1996; Jacobson et al., 2015), while Icelandic spar carbonates have considerably higher ratios of $\sim 6500$ to 360,000 (Jacobson et al., 2015). It follows that 


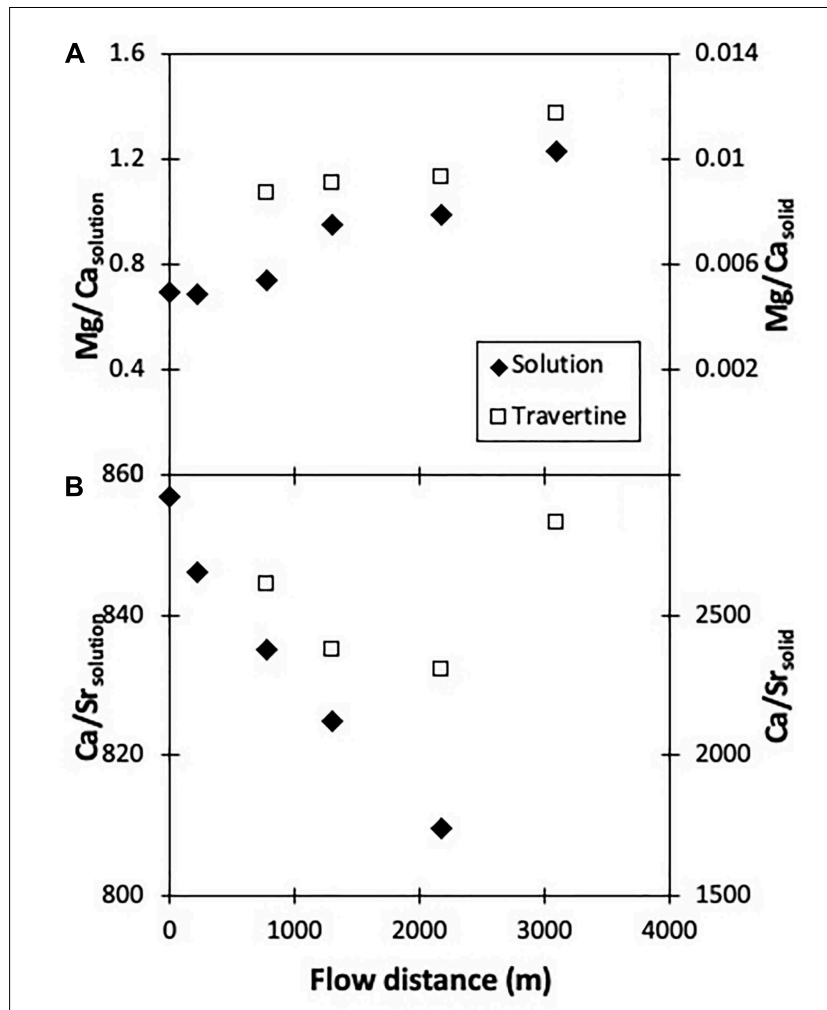

FIGURE 3 | (A) Mg/Ca ratios of the solutions and travertine solids with flow distance. (B) Similar graph for $\mathrm{Ca} / \mathrm{Sr}$ ratios.

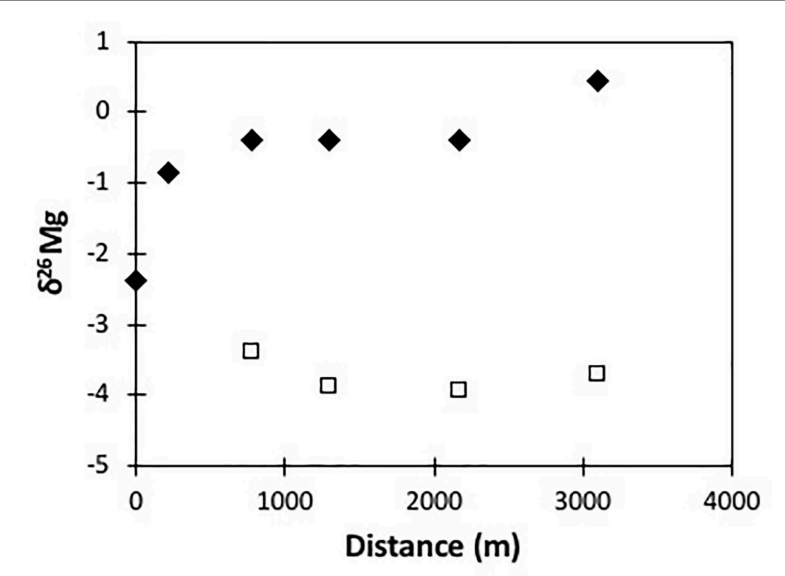

FIGURE 4 | Mg isotope ratios of rivers (closed diamonds) and travertine (open squares) with flow distance from the source under the lava flow of the 2010 Eyjafjallajökull eruption.

the precipitation of calcite from solution will drive the $\mathrm{Ca} / \mathrm{Sr}$ ratio of the solution to lower values than the initial basaltic ratio. The Eyjafjallajökull travertines have an average $\mathrm{Ca} / \mathrm{Sr}$ ratio of $2500 \pm 240 \mathrm{~mol} / \mathrm{mol}$, while the $\mathrm{Ca} / \mathrm{Sr}$ of the river waters decreases almost linearly with distance from 857 to $810 \mathrm{~mol} / \mathrm{mol}$ (Figure 3B). It is highly likely that this decrease is due to calcite precipitation, as other secondary minerals that affect both $\mathrm{Ca}$ and $\mathrm{Sr}$, such as heulandite or stilbite have $\mathrm{Ca} / \mathrm{Sr}$ ratios lower than basalt (Jacobson et al., 2015), and therefore their precipitation would drive solutions to higher values. Overall, this provides further evidence that calcite was actively precipitating from these waters when they were sampled.

\section{Mg Isotopes}

It is unknown exactly why the stream sample from directly beneath the lava flow is so isotopically light for $\mathrm{Mg}(-2.37 \%$, Figure 4). Dissolved inorganic carbon (DIC) and $\mathrm{Ca}$ concentrations in that sample are very high, while the $\mathrm{pH}$ is up to $\sim 2$ units lower than in downstream samples [33 $\mathrm{mM}$, $6.2 \mathrm{mM}$ and $\mathrm{pH}$ 6.6, respectively (Olsson et al., 2014)], and this is the only sample in which calcite is not highly supersaturated (SI calcite $=0.2 \pm 0.5$ - bearing in mind the uncertainty in such snap-shot derived saturation indices). This suggests that the light $\mathrm{Mg}$ isotope ratio is due to dissolved pre-existing subsurface carbonate and/or the infiltration of magmatic $\mathrm{CO}_{2}$, where the former is known to be isotopically light ( $\mathrm{Li}$ et al., 2012; Mavromatis et al., 2012, 2013; Saenger and Wang, 2014), and/or subsurface water-basalt interaction and precipitation of isotopically heavy Si-Al silicates (Wimpenny et al., 2010, 2014) and iron containing phases like ferrihydrite, also driving waters isotopically light. Further, hydrothermal waters generally act as an Mg sink, and hence removal processes could impart substantial isotopic fractionation.

The source spring at the base of the lava flow is approximately at saturation with respect to calcite ( $\mathrm{SI}=0.2 \pm 0.5)$, and the saturation state and $\mathrm{pH}$ rise as the water flows downstream and releases $\mathrm{CO}_{2}$ to the atmosphere, eventually leading to calcite precipitation (highest calcite $\mathrm{SI}=1.7 \pm 0.5$ ). Continuous degassing and calcite precipitation down-stream lowers the in situ partial pressure of $\mathrm{CO}_{2}$ in the water from $10^{-0.5}$ bars in the source spring to $10^{-2.6}$ bars $3.1 \mathrm{~km}$ downstream from the springhead (Figure 2C) (Olsson et al., 2014). As shown in Figure 4, dissolved $\delta^{26} \mathrm{Mg}$ water values begin to increase as isotopically light travertine-calcite is deposited.

The initial increase in $\delta^{26} \mathrm{Mg}$ is very rapid: after $220 \mathrm{~m}$ of flow, solution $\delta^{26} \mathrm{Mg}$ has increased from -2.4 to $-0.9 \%$. By $780 \mathrm{~m}$ of flow, it has increased to $-0.4 \%$. Interestingly, this rapid increase is not matched by $\mathrm{Mg}$ concentrations or $\mathrm{Mg} / \mathrm{Ca}$ ratios, which are stable for the first $780 \mathrm{~m}$. However, the $\mathrm{pH}$ and $\mathrm{pCO}_{2}$ change rapidly in that early section (Olsson et al., 2014). Thus, as $\mathrm{pH}$ increases, $\delta^{26} \mathrm{Mg}$ increases with a strong linear correlation (Figure 5A). Equally, there are similar strong changes in the calcite SI and in $\mathrm{Ca} / \mathrm{Sr}$, which again show co-variation with the $\delta^{26} \mathrm{Mg}$ of the river waters (Figure 5B), implying that it is the precipitation of calcite that is driving the $\mathrm{Mg}$ isotope ratios of the solutions isotopically heavy, and hence that $\mathrm{Mg}$ isotopes are useful tracers of carbonate precipitation processes in these waters.

\section{Modeling Calcite Precipitation Using Mg Isotopes}

Given that the Eyjafjallajökull eruption provides the opportunity to examine a system that appears to be a natural laboratory 


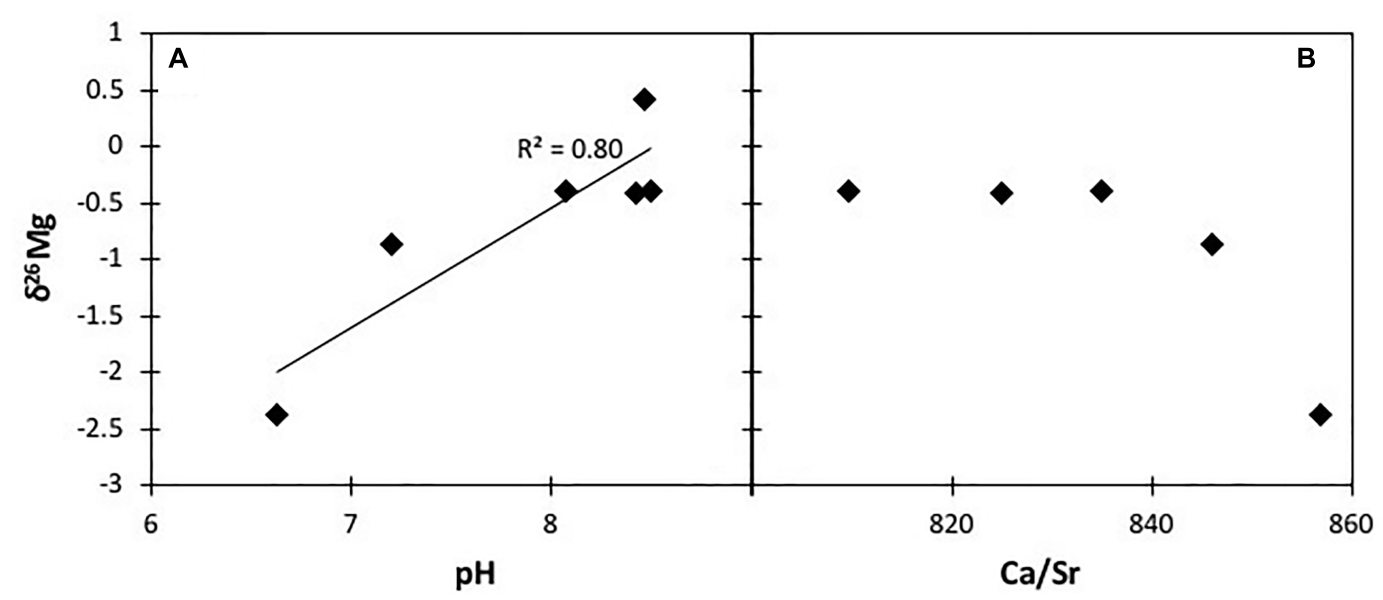

FIGURE 5 | Co-variations between solution $\delta^{26} \mathrm{Mg}$ and $\mathrm{pH}$ (A) and $\mathrm{Ca} / \mathrm{Sr}$ (B).

for calcite precipitation, we can test whether dissolved $\mathrm{Mg}$ isotope ratios can be used to estimate the amount of carbonate that is precipitating. The average measured fractionation factor between the stream samples and their corresponding travertines is $\alpha=0.9965 \pm 0.00047\left(\Delta^{26} \mathrm{Mg}_{\text {solid-soln }}=-3.53\right.$, with a range of -2.98 to -4.14 ), which is within the range determined by experimental studies (Mavromatis et al., 2013; Saenger and Wang, 2014). Using the starting composition of $\delta^{26} \mathrm{Mg}=-2.37 \%$ (the composition of the stream emerging from the lava field), we can calculate the fraction of $\mathrm{Mg}$ remaining in solution relative to that precipitated in carbonates. For this we use a Rayleigh relationship, with the above fractionation factors, and the isotope composition of each stream sample.

$$
f=\left[\frac{\delta_{s}+1000}{\delta_{i}+1000}\right]^{\frac{1}{\alpha-1}}
$$

where $\delta_{i}$ is the $\delta^{26} \mathrm{Mg}$ composition of the initial solution, $\delta_{s}$ is the $\delta^{26} \mathrm{Mg}$ composition of the same, and $\alpha$ is the fractionation factor (Pogge von Strandmann et al., 2012). This then assumes that $100 \%$ of $\mathrm{Mg}$ is in solution in the initial sample, and following this, the fraction decreases to a minimum of $51 \%$ at the furthest point along the stream flow, as increasing amounts of travertine are deposited.

The partition coefficient of $\mathrm{Mg}$ into calcite (i.e., the $\mathrm{Mg} / \mathrm{Ca}$ value) also increases with both the saturation state of calcite and the precipitation rate (Mavromatis et al., 2013). Extrapolating this linear relationship of $\mathrm{D}_{\mathrm{Mg}-\mathrm{CC}}$ vs. $\Omega_{\text {calcite }}$ to the PHREEQCcalculated calcite saturation index of these rivers $[0.2 \pm 0.5$ for the initial location, up to $1.66 \pm 0.5$ where travertine is precipitating (Olsson et al., 2014)], yields partition coefficients $\left(\mathrm{D}_{\mathrm{Mg} / \mathrm{Ca}}\right)$ between $\sim 0.008$ for the initial location, up to $\sim 0.017$. Interestingly, Mavromatis et al. (2013) have also shown that the fractionation factor between experimental calcite and fluid decreases with increasing precipitation rates (or partition coefficient). However, in our data, there is a wide spread in $\Delta^{26} \mathrm{Mg}$ of $\sim 0.5 \%$ for a near-constant $\mathrm{D}_{M g}$ value. In addition, our $\Delta^{26} \mathrm{Mg}$ data do not fall along the same trend line. There are several possibilities as to why the experimental and observational data do not dovetail here, including effects by temperature (the Eyjafjallajökull samples formed at over $20^{\circ} \mathrm{C}$ lower temperatures than the experimental samples), $\mathrm{pH}$ ( $\mathrm{pH}$ was higher by almost 2 units in the natural samples), or fluid composition. This may imply that more experimental work is required to understand any changing $\alpha$ values with precipitation rates, and are therefore not used in our modeling. There is also a postulated speciation effect on Mg isotope fractionation (Schott et al., 2016), implying that a $\mathrm{pH}$ increase will drive carbonate $\delta^{26} \mathrm{Mg}$ lower. We have factored this effect into our model, but for the Eyjafjallajökull samples the effect on the final calcite $\mathrm{Mg} / \mathrm{Ca}$ ratios is small $(<5 \%)$ and within uncertainty (discussed below). The same study (Schott et al., 2016) also suggests an effect whereby declining alkalinity results in higher aqueous $\delta^{26} \mathrm{Mg}$ values, of approximately $-0.01 \% / \mathrm{mM}$ alkalinity. Along the sample flowline here, this would cause the river $\delta^{26} \mathrm{Mg}$ to change by $\sim 0.1 \%$. Correcting for this would change the final $\mathrm{Mg} / \mathrm{Ca}$ ratio by $<3 \%$. We have not factored this correction into our final calculations though, because the results of Schott et al. (2016) were the result of calculations rather than measured data, and in any case the effect is very small and within our uncertainty.

Calculation of the $\mathrm{Mg} / \mathrm{Ca}$ in calcite using only their isotope composition and the partition coefficients (calculated directly when corresponding travertine deposits exist, otherwise using the average) yields ratios that are close to those actually measured (Olsson et al., 2014) (Figure 6 - we note here that Olsson et al. provide both EMPA and leaches of travertines, where $\mathrm{Mg} / \mathrm{Ca}$ are virtually identical in both):

$$
[x]=\left[\frac{(x)_{\text {solution }}}{f}-(x)_{\text {solution }}\right] D
$$

where $[x]$ could either be $[\mathrm{Mg}]$ or $\mathrm{Mg} / \mathrm{Ca}$, depending on what partition coefficient (D) is used. The largest source of uncertainty is inherent in the experimental saturation vs. $\mathrm{D}_{\mathrm{Mg} / \mathrm{Ca}}$ relationship of Mavromatis et al. (2013), and this is 


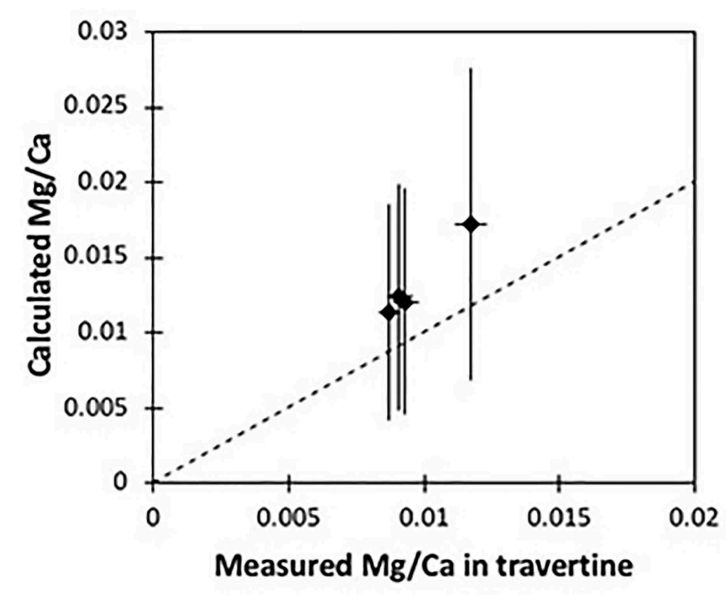

FIGURE 6 | Comparison of the measured molar Mg/Ca ratio of the travertine deposits, compared to the ratios calculated solely from the $\mathrm{Mg}$ isotope composition of the dissolved load (plus fractionation factors and partition coefficients). The dotted line represents a 1:1 relationship. The error bars represent propagated analytical and thermodynamic uncertainties.

factored into the uncertainty calculations for the travertine $\mathrm{Mg} / \mathrm{Ca}$. The uncertainties (Figure 6) are propagated from the analytical uncertainty, the (fixed) uncertainty on the saturation index (included in the partition coefficient D) and the published uncertainty on the fractionation factor, combined using standard error propagation $(\mathrm{Ku}, 1966)$. These uncertainties are approximately $\pm 60 \%$ for the travertine $\mathrm{Mg} / \mathrm{Ca}$ ratios. For the samples for which corresponding travertine exists, the median calculated $[\mathrm{Mg}]$ of the calcite is within a factor of 1.3-1.5 of that actually measured in the travertines, and all samples are within uncertainty of the measured $\mathrm{Mg} / \mathrm{Ca}$. Hence, this approach confirms that it is possible to determine the elemental composition of precipitated carbonate from the $\mathrm{Mg}$ isotope composition of stream waters.

Further, if the water flow rate is known, the calcite precipitation rate can be calculated using the $\mathrm{Mg}$ partition coefficient into calcite. Olsson et al. (2014) determined the flow rate of $0.44 \mathrm{~m}^{3} / \mathrm{s}$ for sample $10 \mathrm{EF} 74$, sampled $220 \mathrm{~m}$ from the lava flow. The small drainage area this close to the source yields a runoff rate of $\sim 1.5 \times 10^{11} \mathrm{l} / \mathrm{km}^{2} / \mathrm{yr}$, which translates to precipitation of $\sim 3200 \mathrm{t} / \mathrm{yr}$ calcite. Uncertainty on this estimate includes analytical uncertainty, and the error on the partition coefficient, runoff, and catchment area. Assuming that the latter two are $\pm 10 \%$, this yields a rate of $3200 \pm 420$ t/yr calcite. Based on PHREEQC modeling, Olsson et al. (2014) estimated that $9100 \mathrm{t} / \mathrm{yr} \mathrm{CaCO}_{3}$ precipitated, assuming that $\mathrm{Ca}$ only precipitated as calcite. Our estimate calculates that $\sim 35 \%$ of $\mathrm{Mg}$ in this sample precipitated into calcite, and this difference in usage efficiency (i.e., how much of dissolved cations are sequestered into calcite) likely causes the difference between our estimate and that of Olsson et al. (2014). Other estimates of volcanicinduced carbonate precipitation includes the 1996 eruption beneath Vatnajökull ice cap, which is estimated to have produced around $1.8 \times 10^{10} \mathrm{~mol}$ of $\mathrm{C}$, from which $\sim 1.1 \times 10^{6} \mathrm{t}$ was precipitated as carbonate in 35 days (Gislason et al., 2002), giving a rate of $\sim 1.15 \times 10^{7} \mathrm{t} / \mathrm{yr} \mathrm{CaCO}_{3}$. During the 2002 glacial flood of the Skaftá River, $2.3 \times 10^{5} \mathrm{t} \mathrm{CO}_{2}$ was drawn down due to carbonate precipitation during the 7 day flood (Galeczka et al., 2015).

Overall, then, the 2010 Eyjafjallajökull eruption was relatively minor in terms of calcite precipitation, but this study does show that $\mathrm{Mg}$ isotopes can be used to estimate carbonate, and hence $\mathrm{CO}_{2}$, precipitation in natural, or potentially artificial settings. A recent study has reported $\mathrm{Mg}$ isotope ratios in waters from the CarbFix mineral carbonation (artificial carbonate precipitation and $\mathrm{CO}_{2}$ drawdown) experiment, also in Iceland (Oelkers et al., 2019). In this experiment, $\delta^{26} \mathrm{Mg}$ values in the groundwaters become lower with time by $\sim 0.7 \%$, which is interpreted as due to the formation of Mg-silicates. In other words, in the CarbFix groundwaters, $\mathrm{Mg}$ uptake by secondary silicates significantly outweighs uptake by carbonates, while in these Eyjafjallajökull samples the processes appear reversed. This is likely due to the overall precipitation rates: in Eyjafjallajökull, the carbonate precipitation rates are extremely fast due to the high TDS, and significantly outweigh the secondary silicate precipitation rates (Olsson et al., 2014). In CarbFix, TDS is significantly lower ( $\mathrm{Mg}$ concentrations are 2-3 orders of magnitude lower), and carbonate precipitation rates are slower (years, rather than a few weeks). Hence it is possible that $\mathrm{Mg}$ isotopes can inform on either or both silicate or carbonate precipitation rates, depending on the setting, and in particular the kinetics of reaction.

\section{CONCLUSION}

This study analyzed $\mathrm{Mg}$ isotope ratios in river waters stemming from beneath a new lava flow from the 2010 Eyjafjallajökull eruption. Travertine carbonate was observed precipitating from these highly concentrated waters, and these travertines were also analyzed. The $\delta^{26} \mathrm{Mg}$ of the waters increases with flow distance, in keeping with the precipitation of isotopically light calcite. The riverine $\mathrm{Mg}$ isotope ratios also co-vary with $\mathrm{pH}$ and calculated calcite saturation indices.

Given the presence of both complementary waters and calcite (i.e., the travertine was directly precipitating from these waters), and that the composition of the precipitated travertines has been measured, this study provides an opportunity to test whether calcite $\mathrm{Mg} / \mathrm{Ca}$ compositions and precipitation rates can be estimated solely from their $\mathrm{Mg}$ isotope composition. The $\mathrm{Mg} / \mathrm{Ca}$ ratios determined solely from $\mathrm{Mg}$ isotope ratios are within uncertainty of those directly measured in the travertines. The overall calcite precipitation rate $(\sim 3200 \mathrm{t} / \mathrm{yr})$ is $\sim 35 \%$ of that calculated for these samples from a PHREEQC model (Olsson et al., 2014). This is consistent with Olsson et al's assumption that all Ca precipitated only as calcite, while calculations using $\mathrm{Mg}$ isotopes suggests that only $35 \%$ of dissolved $\mathrm{Mg}$ is incorporated into calcite.

Overall, then, this suggests that in scenarios where carbonate precipitation is strongly enhanced, such as volcanic eruptions, $\mathrm{Mg}$ isotopes can be used to estimate $\mathrm{CO}_{2}$ draw down when other data are not available. This may also be possible in engineered 
$\mathrm{CO}_{2}$ sequestration reactions, but will depend on the reactions kinetics of the carbonate compared to any secondary Mg-silicates.

\section{AUTHOR CONTRIBUTIONS}

PPvS designed the project, performed the analyses, and wrote the manuscript. JO provided samples and expertise. T-HL assisted with isotope analyses. SG and KB provided expertise and edited the manuscript.

\section{REFERENCES}

Berner, R. A. (2003). The long-term carbon cycle, fossil fuels and atmospheric composition. Nature 426, 323-326. doi: 10.1038/nature02131

Berner, R. A., Lasaga, A. C., and Garrels, R. M. (1983). The carbonate-silicate geochemical cycle and its effect on atmospheric carbon-dioxide over the past 100 million years. Am. J. Sci. 283, 641-683. doi: 10.2475/ajs.283.7.641

Black, J. R., Yin, Q. Z., and Casey, W. H. (2006). An experimental study of magnesium-isotope fractionation in chlorophyll-a photosynthesis. Geochim. Cosmochim. Acta 70, 4072-4079. doi: 10.1016/j.gca.2006.06.010

Bolou-Bi, E. B., Poszwa, A., Leyval, C., and Vigier, N. (2010). Experimental determination of magnesium isotope fractionation during higher plant growth. Geochim. Cosmochim. Acta 74, 2523-2537. doi: 10.1016/j.gca.2010.02.010

Bolou-Bi, E. B., Vigier, N., Poszwa, A., Boudot, J.-P., and Dambrine, E. (2012). Effects of biogeochemical processes on magnesium isotope variations in a forested catchment in the vosges mountains (France). Geochim. Cosmochim. Acta 87, 341-355. doi: 10.1016/j.gca.2012.04.005

Brenot, A., Cloquet, C., Vigier, N., Carignan, J., and France-Lanord, C. (2008). Magnesium isotope systematics of the lithologically varied Moselle river basin, France. Geochim. Cosmochim. Acta 72, 5070-5089. doi: 10.1016/j.gca.2008. 07.027

Buhl, D., Immenhauser, A., Smeulders, G., Kabiri, L., and Richter, D. K. (2007). Time series $\delta 26 \mathrm{Mg}$ analysis in speleothem calcite: kinetic versus equilibrium fractionation, comparison with other proxies and implications for palaeoclimate research. Chem. Geol. 244, 715-729. doi: 10.1016/j.chemgeo. 2007.07.019

Busenberg, E., and Plummer, L. N. (1989). Thermodynamics of magnesian calcite solid-solutions at 25 degrees $\mathrm{C}$ and $1 \mathrm{~atm}$ total pressure. Geochim. Cosmochim. Acta 53, 1189-1208. doi: 10.1016/0016-7037(89)90056-2

Chang, V. T. C., Williams, R. J. P., Makishima, A., Belshawl, N. S., and O’Nions, R. K. (2004). $\mathrm{Mg}$ and $\mathrm{Ca}$ isotope fractionation during $\mathrm{CaCO} 3$ biomineralisation. Biochem. Biophys. Res. Commun. 323, 79-85. doi: 10.1016/j.bbrc.2004.08.053

Dessert, C., Dupre, B., Gaillardet, J., Francois, L. M., and Allegre, C. J. (2003). Basalt weathering laws and the impact of basalt weathering on the global carbon cycle. Chem. Geol. 202, 257-273. doi: 10.1016/j.chemgeo.2002.10.001

Foster, G. L., Pogge von Strandmann, P. A. E., and Rae, J. W. B. (2010). The boron and magnesium isotopic composition of seawater. Geochem. Geophys. Geosyst. 11:Q08015. doi: 10.01029/02010GC003201

Gaillardet, J., Dupre, B., Louvat, P., and Allegre, C. J. (1999). Global silicate weathering and $\mathrm{CO} 2$ consumption rates deduced from the chemistry of large rivers. Chem. Geol. 159, 3-30. doi: 10.1016/S0009-2541(99)00031-5

Galeczka, I., Eiriksdottir, E. S., Hardardottir, J., Oelkers, E. H., Torssander, P., and Gislason, S. R. (2015). The effect of the 2002 glacial flood on dissolved and suspended chemical fluxes in the Skaftaì river, Iceland. J. Volcanol. Geother. Res. 301, 253-276. doi: 10.1016/j.jvolgeores.2015.05.008

Galy, A., Yoffe, O., Janney, P. E., Williams, R. W., Cloquet, C., Alard, O., et al. (2003). Magnesium isotope heterogeneity of the isotopic standard SRM980 and new reference materials for magnesium-isotope-ratio measurements. J. Analyt. Atom. Spectr. 18, 1352-1356. doi: 10.1039/b309273a

Geske, A., Goldstein, R. H., Mavromatis, V., Richter, D. K., Buhl, D., Kluge, T., et al. (2015). The magnesium isotope $(826 \mathrm{Mg})$ signature of dolomites. Geochim. Cosmochim. Acta 149, 131-151. doi: 10.1038/ncomms6328

Geske, A., Zorlu, J., Richter, D. K., Buhl, D., Niedermayr, A., and Immenhauser, A. (2012). Impact of diagenesis and low grade metamorphosis on isotope $(\delta 26 \mathrm{Mg}$,

\section{FUNDING}

Analyses and PPvS were funded by ERC Consolidator grant 682760 CONTROLPASTCO2.

\section{ACKNOWLEDGMENTS}

$\mathrm{CP}$ and another reviewer are thanked for their comments, and JR is thanked for her editing.

$\delta 13 \mathrm{C}, \delta 18 \mathrm{O}$ and $87 \mathrm{Sr} / 86 \mathrm{Sr})$ and elemental $(\mathrm{Ca}, \mathrm{Mg}, \mathrm{Mn}, \mathrm{Fe}$ and $\mathrm{Sr})$ signatures of Triassic sabkha dolomites. Chem. Geol. 332-333, 45-64. doi: 10.1016/j. chemgeo.2012.09.014

Gíslason, S. R., Arnorsson, S., and Armannsson, H. (1996). Chemical weathering of basalt in southwest Iceland: effects of runoff, age of rocks and vegetative/glacial cover. Am. J. Sci. 296, 837-907. doi: 10.2475/ajs.296.8.837

Gislason, S. R., Snorrason, A., Kristmannsdottir, H. K., Sveinbjornsdottir, A. E., Torsander, P., Olafsson, J., et al. (2002). Effects of volcanic eruptions on the CO2 content of the atmosphere and the oceans: the 1996 eruption and flood within the Vatnajokull Glacier, Iceland. Chem. Geol. 190, 181-205. doi: 10.1016/ S0009-2541(02)00116-X

Higgins, J. A., and Schrag, D. P. (2010). Constraining magnesium cycling in marine sediments using magnesium isotopes. Geochim. Cosmochim. Acta 74, 5039-5053. doi: 10.1016/j.gca.2010.05.019

Holland, H. D. (2005). Sea level, sediments and the composition of seawater. Am. J. Sci. 305, 220-239. doi: 10.2475/ajs.305.3.220

Huang, K. J., Teng, F. Z., Wei, G. J., Ma, J. L., and Bao, Z. Y. (2012). Adsorptionand desorption-controlled magnesium isotope fractionation during extreme weathering of basalt in Hainan Island, China. Earth Planet. Sci. Lett. 359-360, 73-83. doi: 10.1016/j.epsl.2012.10.007

Immenhauser, A., Buhl, D., Richter, D., Niedermayr, A., Riechelmann, D. Dietzel, M., et al. (2010). Magnesium-isotope fractionation during low-Mg calcite precipitation in a limestone cave - Field study and experiments. Geochim. Cosmochim. Acta 74, 4346-4364. doi: 10.1016/j.gca.2010. 05.006

Jacobson, A. D., Andrews, M. G., Lehn, G. O., and Holmden, C. (2015). Silicate versus carbonate weathering in Iceland: new insights from Ca isotopes. Earth Planet. Sci. Lett. 416, 132-142. doi: 10.1016/j.epsl.2015.01.030

Jacobson, A. D., and Blum, J. D. (2000). Ca/Sr and $87 \mathrm{Sr} / 86 \mathrm{Sr}$ geochemistry of disseminated calcite in Himalayan silicate rocks from Nanga Parbat: influence on river-water chemistry. Geology 28, 463-466. doi: 10.1130/0091-7613(2000) $28<463$ :SASGOD $>2.0 . \mathrm{CO} ; 2$

Ku, H. H. (1966). Nottes on the use of propagation of error formulas. J. Res. Natl. Bur. Stand. 70C, 263-273.

Li, W. Q., Chakraborty, S., Beard, B. L., Romanek, C. S., and Johnson, C. M. (2012). Magnesium isotope fractionation during precipitation of inorganic calcite under laboratory conditions. Earth Planet. Sci. Lett. 333, 304-316. doi: 10.1016/j.epsl.2012.04.010

Liu, X.-L., Teng, F. Z., Rudnick, R. L., McDonough, W. F., and Cummings, M. L. (2014). Massive magnesium depletion and isotope fractionation in weathered basalts. Geochim. Cosmochim. Acta 135, 336-349. doi: 10.1016/j.gca.2014. 03.028

Mavromatis, V., Gautier, Q., Bosc, O., and Schott, J. (2013). Kinetics of Mg partition and $\mathrm{Mg}$ stable isotope fractionation during its incorporation in calcite. Geochim. Cosmochim. Acta 114, 188-203. doi: 10.1016/j.gca.2013.03.024

Mavromatis, V., Pearce, C. R., Shirokova, L. S., Bundeleva, I. A., Pokrovsky, O. S., Benezeth, P., et al. (2012). Magnesium isotope fractionation during hydrous magnesium carbonate precipitation with and without cyanobacteria. Geochim. Cosmochim. Acta 76, 161-174. doi: 10.1016/j.gca.2011.10.019

Meybeck, M. (1987). Global chemical weathering of surficial rocks estimated from river dissolved loads. Am. J. Sci. 287, 401-428. doi: 10.1007/s11356-015-5503-6

Mucci, A. (1987). Influence of temperature on the composition of magnesian calcite overgrowths precipitated from seawater. Geochim. Cosmochim. Acta 51, 1977-1984. doi: 10.1016/0016-7037(87)90186-4 
Oelkers, E. H., Butcher, R., Pogge von Strandmann, P. A. E., Schuessler, J. A., von Blanckenburg, F., Snaebjornsdottir, S. O., et al. (2019). Using stable Mg isotope signatures to assess the fate of magnesium during the in situ mineralisation of $\mathrm{CO}_{2}$ and $\mathrm{H}_{2} \mathrm{~S}$ at the CarbFix site in SW-Iceland. Geochim. Cosmochim. Acta 245, 542-555. doi: 10.1016/j.gca.2018.11.011

Olsson, J., Stipp, S. L. S., Makovicky, E., and Gislason, S. R. (2014). Metal scavenging by calcium carbonate at the Eyjafjallajökull volcano: a carbon capture and storage analogue. Chem. Geol. 384, 135-148. doi: 10.1016/j. chemgeo.2014.06.025

Opfergelt, S., Burton, K. W., Georg, R. B., West, A. J., Guicharnaud, R. A., Sigfusson, B., et al. (2014). Magnesium retention on the soil exchange complex controlling $\mathrm{Mg}$ isotope variations in soils, soil solutions and vegetation in volcanic soils, Iceland. Geochim. Cosmochim. Acta 125, 110-130. doi: 10.1016/j. gca.2013.09.036

Opfergelt, S., Georg, R. B., Burton, K. W., Delvaux, B., Siebert, C., Guicharnaud, R., et al. (2010). "Magnesium isotope fractionation in volcanic soils controlled by clay mineralogy and exchangeable Mg," in Proceedings of the AGU Fall Meeting, Washington, DC.

Opfergelt, S., Georg, R. B., Burton, K. W., Guicharnaud, R., Siebert, C., Gislason, S. R., et al. (2011). Seasonal magnesium isotope variations in soil solutions reflecting physico-chemical processes controlling soil weathering fluxes. Mineral. Magaz. 75:1571.

Parkhurst, D. L., and Appelo, C. A. J. (1999). "User's guide to PHREEQC (version 2) - a computer program for speciation, batch-reaction, onedimensional transport, and inverse geochemical calculations," in WaterResouces Investigations, (Reston, VA: U.S. Geological Survey).

Pogge von Strandmann, P. A. E. (2008). Precise magnesium isotope measurements in core top planktic and benthic foraminifera. Geochem. Geophys. Geosyst. 9:Q12015. doi: 10.1029/2008GC002209

Pogge von Strandmann, P. A. E., Burton, K. W., James, R. H., van Calsteren, P., and Gislason, S. R. (2008). The influence of weathering processes on riverine magnesium isotopes in a basaltic terrain. Earth Planet. Sci. Lett. 276, 187-197. doi: 10.1016/j.epsl.2008.09.020

Pogge von Strandmann, P. A. E., Elliott, T., Marschall, H. R., Coath, C., Lai, Y. J., Jeffcoate, A. B., et al. (2011). Variations of Li and $\mathrm{Mg}$ isotope ratios in bulk chondrites and mantle xenoliths. Geochim. Cosmochim. Acta 75, 5247-5268. doi: 10.1016/j.gca.2011.06.026

Pogge von Strandmann, P. A. E., Forshaw, J., and Schmidt, D. N. (2014). Modern and cenozoic records of seawater magnesium from foraminiferal $\mathrm{Mg}$ isotopes. Biogeosciences 11, 5155-5168. doi: 10.5194/bg-11-5155-2014

Pogge von Strandmann, P. A. E., Opfergelt, S., Lai, Y. J., Sigfusson, B., Gislason, S. R., and Burton, K. W. (2012). Lithium, magnesium and silicon isotope behaviour accompanying weathering in a basaltic soil and pore water profile in Iceland. Earth Planet. Sci. Lett. 339-340, 11-23. doi: 10.1016/j.epsl.2012.05.035

Saenger, C., and Wang, Z. (2014). Magnesium isotope fractionation in biogenic and abiogenic carbonates: implications for paleoenvironmental proxies. Quat. Sci. Rev. 90, 1-21. doi: 10.1016/j.quascirev.2014.01.014

Saulnier, S., Rollion-Bard, C., Vigier, N., and Chaussidon, M. (2012). Mg isotope fractionation during calcite precipitation: an experimental study. Geochim. Cosmochim. Acta 91, 75-91. doi: 10.1016/j.gca.2012.05.024

Schott, J., Mavromatis, V., Fujii, T., Pearce, C. R., and Oelkers, E. H. (2016). The control of carbonate mineral $\mathrm{Mg}$ isotope composition by aqueous speciation: theoretical and experimental modeling. Chem. Geol. 445, 120-134. doi: 10.1016/ j.chemgeo.2016.03.011

Shalev, N., Farkas, J., Fietzke, J., Novak, M., Schuessler, J. A., Pogge von Strandmann, P. A. E., et al. (2018). Mg isotope inter-laboratory comparison of reference materials from earth-surface low-temperature environments. Geostand. Geoanalyt. Res. 42, 205-221. doi: 10.1111/ggr.12208

Teng, F. Z., Li, W. Y., Rudnick, R. L., and Gardner, L. R. (2010). Contrasting lithium and magnesium isotope fractionation during continental weathering. Earth Planet. Sci. Lett. 300, 63-71. doi: 10.1016/j.epsl.2010.09.036

Teng, F. Z., Yin, Q. Z., Ullmann, C. V., Chakrabarti, R., Pogge von Strandmann, P. A. E., Yang, W., et al. (2015). Interlaboratory comparison of magnesium isotopic compositions of 12 felsic to ultramafic igneous rock standards analyzed by MC-ICPMS. Geochem. Geophys. Geosyst. 16, 3197-3209. doi: 10.1002/ 2015GC005939

Tipper, E. T., Calmels, D., Gaillardet, J., Louvat, P., Capmas, F., and Dubacq, B. (2012a). Positive correlation between $\mathrm{Li}$ and $\mathrm{Mg}$ isotope ratios in the river waters of the Mackenzie Basin challenges the interpretation of apparent isotopic fractionation during weathering. Earth Planet. Sci. Lett. 333, 35-45. doi: 10. 1016/j.epsl.2012.04.023

Tipper, E. T., Lemarchand, E., Hindshaw, R. S., Reynolds, B. C., and Bourdon, B. (2012b). Seasonal sensitivity of weathering processes: hints from magnesium isotopes in a glacial stream. Chem. Geol. 312-313, 80-92. doi: 10.1016/j. chemgeo.2012.04.002

Tipper, E. T., Gaillardet, J., Louvat, P., Capmas, F., and White, A. F. (2010). Mg isotope constraints on soil pore-fluid chemistry: evidence from Santa Cruz, California. Geochim. Cosmochim. Acta 74, 3883-3896. doi: 10.1016/j.gca.2010. 04.021

Tipper, E. T., Galy, A., and Bickle, M. (2008). Calcium and magnesium isotope systematics in rivers draining the himalaya-tibetan-plateau region: lithological or fractionation control? Geochim. Cosmochim. Acta 72, 1057-1075. doi: 10. 1016/j.gca.2007.11.029

Tipper, E. T., Galy, A., and Bickle, M. J. (2006a). Riverine evidence for a fractionated reservoir of $\mathrm{Ca}$ and $\mathrm{Mg}$ on the continents: implications for the oceanic Ca cycle. Earth Planet. Sci. Lett. 247, 267-279. doi: 10.1016/j.epsl.2006.04.033

Tipper, E. T., Galy, A., Gaillardet, J., Bickle, M. J., Elderfield, H., and Carder, E. A. (2006b). The magnesium isotope budget of the modern ocean: constraints from riverine magnesium isotope ratios. Earth Planet. Sci. Lett. 250, 241-253. doi: 10.1016/j.epsl.2006.07.037

Walker, J. C. G., Hays, P. B., and Kasting, J. F. (1981). A negative feedback mechanism for the long-term stabilization of earths surfacetemperature. J. Geophys. Res. Oceans Atmosph. 86, 9776-9782. doi: 10.1029/ JC086iC10p09776

Wimpenny, J., Burton, K. W., James, R. H., Gannoun, A., Mokadem, F., and Gislason, S. R. (2011). The behaviour of magnesium and its isotopes during glacial weathering in an ancient shield terrain in West Greenland. Earth Planet. Sci. Lett. 304, 260-269. doi: 10.1016/j.epsl.2011.02.008

Wimpenny, J., Colla, C. A., Yin, Q. Z., Rustad, J. R., and Casey, W. H. (2014). Investigating the behaviour of $\mathrm{Mg}$ isotopes during the formation of clay minerals. Geochim. Cosmochim. Acta 128, 178-194. doi: 10.1016/j.gca.2013. 12.012

Wimpenny, J., Gislason, S. R., James, R. H., Gannoun, A., Pogge von Strandmann, P. A. E., and Burton, K. W. (2010). The behaviour of Li and $\mathrm{Mg}$ isotopes during primary phase dissolution and secondary mineral formation in basalt. Geochim. Cosmochim. Acta 74, 5259-5279. doi: 10.1016/j.gca.2010.06.028

Wolff-Boenisch, D., Gislason, S. R., and Oelkers, E. H. (2006). The effect of crystallinity on dissolution rates and $\mathrm{CO} 2$ consumption capacity of silicates. Geochim. Cosmochim. Acta 70, 858-870. doi: 10.1016/j.gca.2005. 10.016

Wombacher, F., Eisenhauer, A., Bohm, F., Gussone, N., Regenberg, M., Dullo, W. C., et al. (2011). Magnesium stable isotope fractionation in marine biogenic calcite and aragonite. Geochim. Cosmochim. Acta 75, 5797-5818. doi: 10.1016/j. gca.2011.07.017

Conflict of Interest Statement: The authors declare that the research was conducted in the absence of any commercial or financial relationships that could be construed as a potential conflict of interest.

Copyright (c) 2019 Pogge von Strandmann, Olsson, Luu, Gislason and Burton. This is an open-access article distributed under the terms of the Creative Commons Attribution License (CC BY). The use, distribution or reproduction in other forums is permitted, provided the original author(s) and the copyright owner(s) are credited and that the original publication in this journal is cited, in accordance with accepted academic practice. No use, distribution or reproduction is permitted which does not comply with these terms. 